\title{
$402 \mathrm{Mr}$. C. C. Babington on Statice Dodartii and S. occidentalis.
}

root of the pectoral and the posterior margin of the eye. Uniform brown.

This is another new species from the Cape Seas, closely allied to $E$. albescens, from which it differs by its narrower mouth, its shorter ventral fin, and also by the smaller number of the laminæ of the disk. To which of the two species the figure given by Dampier (Voyage to New Holland, i. pl. 1. fig. 6) ought to be referred is a question that cannot be decided.

In conclusion, I give a synoptical review of the species enumerated*:-

a. Species with a stout and rather short body.

No. of laminæ.

1. E. clypeata, Gthr. • • . . 12

2. E. albescens, Schleg. . . . . 13

3. E. squalipeta, Daldorf . . . . 17

4. E. brachyptera, Lowe . . . 15-16

5. E. remora, L. . . . . . 17-18

6. E. osteochir, Cuv. • • . . . 19

7. E. scutata, Gthr. . . . . 27

B. Species with a slender body.

8. E. lineata, Menzies . . . . . 10

9. E. Holbrookii, Gthr. . . . . 21

10. E. naucrates, L. . . . . . . 22-25

XLIII.-Note concerning Statice Dodartii and S, occidentalis. By C. C. Babington.

IN the year 1849 I published a paper in these 'Annals' (ser. 2. iii. 433) "On the British Plumbaginacex," pointing out that the plant erroneously called S. spathulata or S, cordata in this country is the S. occidentalis (Lloyd). I also endeavoured to show that the $S$. Dodartii (Gir.) inhabited our western coasts. At that time, and until very recently, I had not seen an au-

* While this paper was passing through the press, my attention was called to the announcement of one on the same subject by M. Duméril (Compt. Rend. 1858, p. 374), in which he enumerates forty-six species which are to be described by him. He does not appear to be aware of the variability of the number of the laminæ and fin-rays, nor of the variation of the form of the caudal fin. He states that he has examined 161 specimens,- a number scarcely exceeding that examined by myself, the British Museum alone possessing 130 specimens. The difference in the treatment of the subject, therefore, is so great, that there is no reason to hold back this paper on account of that advertisement,-the less as, perhaps, M. Duméril may obtain from it some information that may prove useful to him. 
thentic specimen of $S$. Dodartii; but now possessing one in Billot's valuable 'Exsiccatæ' (No. 1054), I have again submitted our plants to a careful examination. It was my opinion that specimens gathered at Berry Head (Devon), Giltar Head (Pemb.), and Pennard and Langland Bay (Glam.), were the true S, Dodartii, notwithstanding "a few slight discrepancies" in the description. But as a considerable addition has been gradually made to my set of specimens, so has my opinion tended more and more towards the belief that these plants ought not to be separated from S. occidentalis : the receipt of Dr. Billot's specimen of the true S. Dodartii shows that they are not identical with it, and removes the only difficulty that I found in considering them all as $S$, occidentalis.

The specific distinctness of S. Dodartii is still open to discussion, but I do not possess the materials requisite for entering upon so difficult an inquiry. All the more modern French botanists-Godron, Lloyd, and Boreau, for instance-separate them; and assuredly the authentic specimens have a very different appearance, although it is not easy to define in botanical language their distinctive points. Speaking generally, it may be remarked that $S$. Dodartii is a coarser plant than $S$, occiden. talis; its stems are stouter; leaves thicker, and blunt; spikes broader, owing to the spikelets being more closely placed, and therefore more spreading; inner bracts very broad and blunt, and with a narrower scarious margin.

But at the same time that the authority for including $S$. Dodartii in the British Flora is destroyed, I am enabled to show cause for its restoration to our catalogue. There has long been an unnamed specimen of Statice in my herbarium, which was gathered at Portland, Dorset, in September 1832, by Professor Henslow. This is quite similar to the authentic S. Dodartii supplied to me by Billot, agrees well with Girard's description (Ann. Sc. Nat, 2 sér, xvii. 31), and is exceedingly like the fine old plate of Limonium minus, Bellidis minoris folio, to be found in Dodart's 'Mémoires' (ed. 1. p. 95). It is a coarse, inelegant plant, of a very different aspect from any state of $S$. occidentalis. The distribution of this plant has to be determined; for it is scarcely to be supposed that Portland is its only English station. Botanists visiting our south coast in the latter part of the sum, mer would do well to pay attention to these plants, so as to determine their extent of variation and range. S. Dodartii seems to be the less common plant on the French side of the Channel. Iloyd only mentions it as tolerably plentiful on the north coast of Bretagne; but it seems to be more abundant on the western coast of France.

$\mathrm{Mr}$. Bentham combines these two species, and gives them the 
name of S. auriculafolia. The plant so named in his 'Cat. des Pl. des Pyrénées' is referred by all the French botanists to the S. lychnidifolia (Gir.); but surely Mr. Bentham would not combine our plants with it! That would be a union more remarkable even than many of the other conjunctions of species which he expects us to accept upon his authority alone.

XLIV.-On a Species of Ostrea taken from the copper sheathing on the bottom of a vessel in the Liverpool Graving Docks. By T. C. Archer, Professor of Botany in Queen's College, Liverpool.

The great rarity of the occurrence of bivalve shells growing upon the bottoms of ships is well known to those who are engaged in the repairs of vessels ; two such instances, however, have occurred in this port, within a few weeks of each other. In the first case, which did not fall under my own notice, the copper sheathing of a vessel from Bombay was found to have attached to it a considerable number of full-grown shells of a species closely allied to Ostrea edulis. In the second instance, I happened to pass one of our graving docks in which some vessels were undergoing repairs, and was much struck with the immense number of oyster-shells adhering to the bottom of one of them. Upon descending for the purpose of a closer inspection, I found one or two old ship-carpenters examining them with great curiosity; and they informed me that, although they had worked in the Graving Docks from their boyhood, they had never seen oysters on a ship's bottom before. I removed a few of the shells, which thickly covered the greater part of the copper, being thickest near the keel, and took them away for examination. On my return home, I saw at once that it was a species with which I was not familiar, and upon referring. to the beautiful and extensive collection in the Liverpool Royal Institution, I found no specimen of the species there; nor have I been able by reference to local and distant friends to ascertain its name. I therefore hastened to secure a considerable number of specimens for distribution - and was only just in time, for they were being rapidly removed and carted away: upwards of $a$ ton and $a$ half were supposed to have been taken from the ship's bottom.

Deeply imbedded in the interstices of the clumps of oysters, I discovered some small shells attached by a byssus; these are a species of Perna, which Mr. S. P. Woodward obligingly informs me is known to him as a South Sea species. This is of value, as indicating the probable habitat of the Ostrea, otherwise a difficult matter, for very little is known of the antecedents of the vessel, she having been taken as a prize during the Russian war, 


\section{$2 \mathrm{BHL}$ Biodiversity Heritage Library}

Babington, Charles Cardale. 1860. "XLIII.-Note concerning Statice Dodartii and S. occidentalis." The Annals and magazine of natural history; zoology, botany, and geology 5, 402-404.

View This Item Online: https://www.biodiversitylibrary.org/item/19558

Permalink: https://www.biodiversitylibrary.org/partpdf/39858

\section{Holding Institution}

Natural History Museum Library, London

\section{Sponsored by}

Natural History Museum Library, London

\section{Copyright \& Reuse}

Copyright Status: Public domain. The BHL considers that this work is no longer under copyright protection.

This document was created from content at the Biodiversity Heritage Library, the world's largest open access digital library for biodiversity literature and archives. Visit BHL at https://www.biodiversitylibrary.org. 